\title{
The Development of Chemistry Textbook Based on Scientific Literacy
}

\author{
Vivi Seftari, Burhanudin Milama, Nanda Saridewi \\ Syarif Hidayatullah State Islamic University St. Ir. H. Juanda No. 95, Ciputat, Jakarta, Indonesia, \\ Corresponding e-mail: viviseftari93@gmail.com
}

\begin{abstract}
The qualities of student science literacy skills were still below the standard, one of the reason was the absent of chemistry textbook which provide student to integrate with the development of science in the factual aspect with our daily lives. The research aims to develop chemistry textbook based on science literacy on colloid system. It used development research method with ADDIE (Analyze, Design, Development, Implementation, and Evaluation). The data were analysed in descriptive method. The result of this research was the chemistry textbook which were integrated with the indicators of science literacy. It was validated based on suitable content aspect presentation aspect, and language aspect. The result of this research shown that chemistry textbook based on science literacy had Excellent response with $84,90 \%$ percentage.
\end{abstract}

Keywords: textbook development, chemistry textbook, literacy science, colloid, ADDIE.

\section{INTRODUCTION}

Science education is a vehicle for students to understand the environment, health, economy, and other problems faced by modern society in which the modern society relies heavily on technology and progress, as well as the development of science. The purpose of science education is to increase the competencies required by learners to be able to meet their needs in various situations. For that required the ability of science literacy students in the expectation that students understand science and technology that continues to grow over time and can apply it in daily life.

Coughlan (2015) wrote that the literacy ability of student science in Indonesia can be seen from the 2015 PISA report which Indonesia is ranked 69 out of 76 participating countries, or in other words, the eighth lowest ranking of all PISA participating countries. The low ability of students 'science literacy indicates that the learning process of science schools in Indonesia has neglected the ability of students' science literacy. This condition demands improvement and renewal to improve the quality of student science learning.
The existence of teaching materials as the main source of learning in school is one of the factors directly used in the learning process of students and affects the low literacy skills of Indonesian students (Kurnia, et al., 2014, p.43). The existe nce of teaching materials is an important factor in supporting the success of learning because the teaching materials can connect, even can combine the experience and knowledge of learners (Toharudin, et al., 2011, p.182).

Teaching materials are learning materials in the form of a collection of knowledge (facts, concepts, principles and procedures), skills, and attitudes or values that must be learned to achieve the desired learning goals (Zulfiani, et al., 2009, p 37). Meanwhile, according to Prastowo (2011, p.17), teaching materials are various materials that are arranged systematically in the form of information, tools, and text, used in the learning process and display the competencies that must be mastered by the students, for instance, textbooks, modules, handouts, student worksheets, audio teaching materials, and so forth.

One type of teaching material that has a role as a primary source for students to obtain information 
during the learning process is textbooks (Sothayapetch, 2013, p. 16). Textbooks that can be said to be the same as textbooks have definitions as a book used for a particular lesson that has a standardized standard, structured for specific instructional purposes, and equipped with teaching tools that are easily understood by the wearer to support high school learning and high (Tarigan and Tarigan, 2009, p. 13-14).

Textbooks have several characteristics, which provide benefits in the learning process, display different forms of activity, and provide assistance in the learning process (Sothayapetch, 2013, p. 25). Judging from the explanation can be said textbook can be a source of learning for students who can build the ability of science literacy students because it can help students in the learning process.

The ability of science and technology literacy can be improved, one way is the presentation of science teaching materials in schools should always be linked and synchronized with social and technological issues of society. Sanjaya (2008, p. 141) argued that the subject matter has an important role to enhance the students' understanding of science, and the success of a learning process. However, in fact the existing books in schools have not been able to build students' science literacy skills. This is also consistent with the results of interviews conducted in August 2015 that the circulating books contain only the material without loading the problems and the development of science in everyday life. Although there is the only limited introduction to learning (Marlina, 2015). Besides, it has not shown the positive and negative effects of science for society and many more science literacy indicators that have not been published in the books used in schools.

In order for textbooks to help build literacy societies in the field of science and technology, it is necessary to prepare a balanced lesson that emphasizes knowledge, inquiry, though, history of science, and concern for technology and social (Udeani, 2013, p. 40). Yager (1983, p. 586), however, stated that most textbooks emphasize the term and vocabulary so that students only remember all the information and use that information to answer the test, then assume that it is a science. This statement is also supported by the statement from Hayat and Yusuf (2011, p. 409-410) that science textbooks for secondary education in Indonesia are still unable to meet expectations resulting in the low quality of student learning.

Given the importance of the role of books in learning and still have limitations, it is necessary to develop textbooks capable of building students' literacy skills science. Reinforced by the statement of Hayat and Yusuf (2011, p.412) suggesting the need for improvement of textbooks and supporting books that do not improve the quality of literacy. One of the materials related to the phenomenon of phenomena in society and also related to technological progress is colloidal material. For that, the researcher is focused on the development of chemistry textbooks based on science literacy on the material colloidal system.

This research aims to: (1) Develop sciencebased literacy book of science on colloidal system material, (2) to know the user's response to the use of science-based literacy book of science that has been developed. With the hope that this book developed can be used as a learning reference and can improve students 'understanding of colloidal materials that can improve students' literacy skills.

\section{METHODS}

\subsection{Types of research}

This research used research and development method with five stages of ADDIE model: analyze, design, develop, implement, and evaluate. Activities in the five stages have then disclosed the implementation. The analysis phase was carried out from June 2015 August 2015, the design phase was implemented in September 2015 - October 2015, the development stage of November 2015 - February 2016, the implementation phase of March 2016 which lasted approximately 1 day, while the evaluation stage was done in every stage.

The test subjects in this study were students of SMA Negeri 86 Jakarta class XI in the even semester of the academic year 2015/2016 as many as 31 students.

\subsection{Research Design}

The first stage is the analysis stage. At this stage identification of what causes the occurrence of performance gaps in schools. Information obtained through interviews related to the condition of students, teachers, and schools that will be a sample of research.

The second is the design stage, this stage aims to verify the performance and appropriate assessment to determine student learning outcomes. At this stage, formulating task, formulating content and formulating test, compiled into a booka later stage, were done. 
The third step is the development that aims to produce the product and validate it. At this stage what is done is to prepare everything, related to the making of books and the manufacture of instruments used during the trial. Activities undertaken at this stage are book development, book validation, develop a lesson plan and questionnaire making of student responses. Book development is made from the formulation of content that has been created at the design stage. Book validation is conducted as a basis for revising books and knowing book readiness for a limited trial. Developing a lesson plan is done as a preparation for the use of books in the classroom during the trial process is limited. The student response questionnaire contained a positive statement of 25 items relating to the assessment for a chemistry book that included the content feasibility aspect, presentation aspect and the aspect of the discourse.

Fourth is the stage of implementation by applying or using products that have been made. At this stage, the use of the product is intended to be tested. Students use the developed product and then respond to the use of the book using a student response questionnaire.

The fifth stage is the evaluation, which aims to assess the quality of the book, both before and after implementation. In this step, it is done to improve the product based on the conclusions of the data obtained during the trial. But basically, the evaluation is done at every stage of development in the form of revision activities made based on input from the research supervisor. Systematically this development stage is described in Figure 1.

Figure 1. Design of Learning Book Development

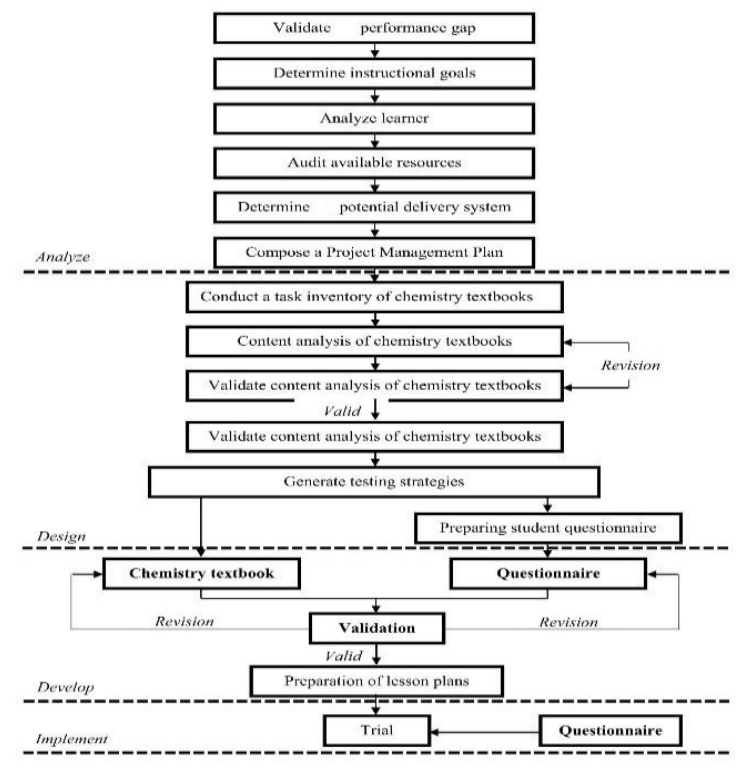

\subsection{Data Collection Techniques}

Data collection techniques that used in the process of developing this book are interviews, validation sheets, and student response questionnaires. The instrument used in this interview is an interview guide which contains a number of questions about chemistry learning, students' science literacy skills, and chemistry books used. Interviews were conducted with 3 chemistry teachers and 3 high school students in South Jakarta to analyze the performance gap in school. Interview data were then reduced to the conclusion of the interview. Meanwhile, the technique of collecting data by using questionnaire of student response is done by giving some written question to the student to get data about student's response to the use of science-based chemistry literacy book on the material of colloidal system that has been developed. The student response data were obtained from a questionnaire given to 31 students after using a chemistry book that has been developed. Students give a check $(\sqrt{ })$ on the column or place that has been provided in accordance with the alternative answer selected. The questionnaire contains 20 statements using the Likert scale with four alternative answers, Strongly Agree, Agree, Disagree, and Strongly Disagree.

However, before tested, the previous developed response book and the questionnaire was validated to determine its eligibility. The student questionnaire validation sheet was given to 2 expert lecturers while the book validation sheet was given to 3 expert lecturers and 1 chemistry subject teacher to request the assessment and input of the experts. The completed validation sheet will become the reference in revising the book and questionnaire of student response before it is tested. The instrument used is a Guttman scale questionnaire in the form of two alternative answers: "Yes" and "No". This instrument indicator refers to the instrument of students' book appraisal from Badan Standar Nasional Pendidikan (BSNP) which covers feasibility of content, presentation and linguistic.

\subsection{Data Analysis Technique}

Data obtained through product validation by experts based on the Guttman scale gives data of two alternative answers, "Yes" and "No". Answers are made with the highest score being 1 and the lowest 0 (Arikunto, 2013, p. 285). From the scoring obtained a total score which is the sum of scores validation results and maximum score which is the sum of 
statements on the validation sheet. Then the resulting data is determined a percentage of validation results through the calculation of percentage determination that is as follows:

$$
\text { Percentage }=\longleftarrow \text { x } 100 \%
$$

The validity of the product and the research questionnaire is done until $100 \%$ of each validator is obtained so that the research products and questionnaires are ready for the limited test phase.

While in the student response questionnaire done scans Likert scale as follows:

Table 1. Scoring Likert Scale

\begin{tabular}{|c|c|c|c|c|}
\hline $\begin{array}{l}\text { Symb } \\
\text { ol }\end{array}$ & $\begin{array}{l}\text { Positive } \\
\text { Statements }\end{array}$ & Score & $\begin{array}{l}\text { Negative } \\
\text { Statements }\end{array}$ & Score \\
\hline$\overline{\mathrm{SA}}$ & $\begin{array}{l}\text { Strongly } \\
\text { Agree }\end{array}$ & 4 & $\begin{array}{l}\text { Strongly } \\
\text { Agree }\end{array}$ & 1 \\
\hline A & Agree & 3 & Agree & 2 \\
\hline DA & Disagree & 2 & Disagree & 3 \\
\hline SDA & $\begin{array}{l}\text { Strongly } \\
\text { Disagree }\end{array}$ & 1 & $\begin{array}{l}\text { Strongly } \\
\text { Disagree }\end{array}$ & 4 \\
\hline
\end{tabular}

Data obtained from student questionnaire results recapitulated into the table so that all answers from all respondents will be seen. The answers of all respondents on each item statement (total item score) divided by the maximum value of each question and multiplied by $100 \%$, so as to get the percentage value of each item statement. Then can be searched average percentage value assessor aspect and overall through calculation as follows:

$$
\stackrel{\text { score }}{100 \%}
$$

Data analysis is done at every stage of development. Analysis of the data is done by describing everything that has been done. While the data analysis for the results of questionnaire responses of students, first done interpretation score numbers into a questionnaire.

Table 2. Criteria Score Interpretation

\begin{tabular}{lll}
\hline No & Interval Score & Category \\
\hline 1 & $81-100 \%$ & Very Good \\
2 & $61-80 \%$ & Good \\
3 & $41-60 \%$ & Pretty Good \\
4 & $21-40 \%$ & Less Good \\
5 & $0-20 \%$ & Very Less Good \\
\hline
\end{tabular}

The result of the interpretation obtained shows the user's response to chemistry-based literacy book of science on the material of colloidal system that has been developed.

\section{RESULTS AND DISCUSSION}

The purpose of this research is to develop textbook of chemistry based on science literacy on colloidal system material and to know the user's response to the developed chemistry book. The mining of the book is developed following the development stage of the ADDIE model (Analyze, Design, Development, Implementation, and Evaluate).

In the analysis, phase begins by analyzing performance gaps. Based on the results of interviews with 3 teachers and 3 students of grade XI in South Jakarta, there was a performance gap that students had difficulties in understanding the learning of chemistry and did not have to apply science knowledge in their daily life and their relationship with community technology. This is caused by the book used to explain more theories than applying chemistry in everyday life. In addition, the book used is also unable to assist students in using their knowledge in searching, interpreting, identifying evidence, drawing conclusions, communicating conclusions through experiments. So as not to arouse students' curiosity and motivate students to solve problems related to the science of technology and society. So the current chemistry book needs to be developed again.

One of the chemicals related to the student environment is colloidal. In colloidal material the students are not enough to use only their memorization to understand colloid material, but it is necessary to understand and memorize enough from students such as understanding of colloid in general, colloid types and ways of making colloid, so that students can apply their knowledge in daily life (Dewantari, et al., 2013, p.143). The colloid material provides students with extensive benefits in the fields of food, pharmacy, and industry.

The next step in the analysis phase is the formulation of the instructional objectives. The formulation of instructional objectives aims to cover the performance gaps found in the performance gap analysis stage. A goal that can mask the performance gap is to create a chemistry teaching material that helps students understand important concepts related to natural phenomena and help to use their knowledge in searching, interpreting, identifying evidence, drawing conclusions, communicating conclusions through experiments that generate curiosity know 
students and motivate, students to solve problems related to science technology and society on colloidal material. This objective will be re-described as a special purpose. From this formulation obtained the division of matter into 4 sub-matrices, namely understanding colloids, colloidal types, colloidal properties, and colloid making.

After performing the formulation of the instructional objectives, the next step is the analysis of student characteristics. From the results of the literature review on the characteristics of students, students at high school level are able to integrate what they have learned by an application in the student environment so that students are able to solve problems logically based on the knowledge they have learned. What connects this performance gap and the characteristics of students in the science literacy, where the science literacy indicator can mask the performance gap and matches the characteristics of students at the senior high school level. Beside, thing concerned in science education nowadays is science literacy. Therefore, the appropriate strategy to cover the performance gap is to create or develop chemistry books based on science literacy on colloidal system material. This is the final step in the analysis phase of formulating the right strategy to cover the performance gap.

In the design, the stage is to formulate what tasks that can achieve instructional goals. The resulting task is what content will be presented in the chemistry book that will be developed where the content contains science literacy indicators so that students can relate the knowledge gained with experience in daily life related to community technology. Chiappetta, et al. (1991, p. 940) stated that chemical textbooks should assist students in building knowledge of science and technology in society. Next thing to do is content analysis. Where the content to be presented in a chemical book is first adapted to the science literacy indicator, resulting in a literaturebased chemical literature of science. The suitability of science literacy indicator with the material to be presented first validated, after valid then the material is ready presented into the book developed.

The next step formulates the tests to be published in a developed chemistry book. The formulation of the test in the book is arranged in the form of a practicum, exercise questions at the end of the section, and practice questions at the end of the book. The test in the form of a practicum of questions at the end of the lab aimed to measure students' understanding of practicum. While the test in the form of exercise questions at the end of the section is given in the form of a description and exercise questions at the end of the book are given in the form of multiplechoice questions. The exercise at the end of the subheadings and the exercise questions at the end of the book are based on indicators.

At the stage of development is done draft writing. During the process of writing the material selection books, discourses, and illustrations as outlined in the book also become a matter of concern. In the selection of materials, four scientific literacy indicators consisting of science as the body of knowledge, science as a way of investigating, science as a way of thinking, and the interaction of science, technology, and society are essential to be presented in developed books. So at this stage, the researchers integrate the colloidal material with the indicator of science literacy in every page of the book. One of the components that should be published in chemistry books based on science literacy is the linkage of science, technology, and society. In addition, chemistry books should also make students know how the influence of technology on the environment of society so that students are expected to have concern for the environment of life (Susanti, et al., 2015, p.44).

The book is organized into three sections comprising the beginning, content, and ending. The first part consists of the cover of the book (cover), the identity of the book, the preface, the book instructions, and the table of contents, the concept map, and the keywords. The content section contains material expositions on colloidal system materials that are integrated with science literacy indicators. Systematic presentation of the material and examples and illustrations are interesting. This is done to clarify the content of the material and to assist the students in understanding the material. In addition, color selection is also one of the attractions that motivated students to read chemistry books developed. One of the student's guidance and drawing tools for important information is the use of appropriate colors (Arsyad, 2010, p. 91). While at the end there is a summary, exercise questions, glossary, bibliography and key answers.

After the book is completed, the next step is validation done by 3 experts (lecturers) and 1 educational practitioner (teacher). Expected from this validation are suggestions and inputs from validators who are considered to revise the draft chemistry book that has been developed. Validation is done until all validator gives $100 \%$ result. The development of validation values is presented in Table 3 
Table 3. Perkembangan Validitas Produk

\begin{tabular}{lllll}
\hline Validator & I & II & III & IV \\
\hline 1 & $98,33 \%$ & $100 \%$ & & \\
2 & $100 \%$ & & & \\
3 & $96,67 \%$ & $91,67 \%$ & $98,33 \%$ & $100 \%$ \\
4 & $98,33 \%$ & $100 \%$ & & \\
\hline Average & $98,33 \%$ & $97,22 \%$ & $98,33 \%$ & $100 \%$ \\
\hline
\end{tabular}

The most dominant suggestion in the validation process is about illustration, consistent term, spelling, and layout. And all suggestions and inputs are then used as materials to revise the draft chemistry book to produce a chemistry book that is ready to be tested.

In the Implementation, the stage is to make Learning Implementation Plan to simulate the use of chemistry books in the classroom. Furthermore, a limited trial was conducted using a chemistry book on the learning process on subcultural understanding and colloidal types. At the end of the study, the researchers conducted a questionnaire that has been declared valid by the validator questionnaire response students. The questionnaire contains 20 statements containing the content feasibility aspects, components of presentation and components of the discussion. This questionnaire is intended to get students' responses to the chemistry books that have been developed. Data obtained from the student response questionnaire can be seen in Table 4.

Table 4. Data of Student Response Results

\begin{tabular}{llll}
\hline No & Aspect & $\begin{array}{l}\text { Average } \\
\text { Aspect }\end{array}$ & Criteria \\
\hline 1 & $\begin{array}{l}\text { Feasibilityof } \\
\text { Content }\end{array}$ & $83,22 \%$ & Very Good \\
2 & $\begin{array}{l}\text { Serving } \\
\text { Components }\end{array}$ & $86,47 \%$ & Very Good \\
3 & $\begin{array}{l}\text { Linguistic } \\
\text { Components }\end{array}$ & $85,01 \%$ & Very Good \\
\hline & Average & $\mathbf{8 4 , 9 0 \%}$ & Very Good \\
\hline
\end{tabular}

Based on the data of the calculation of the percentage of students questionnaire responses obtained that the percentage of the average assessment of chemistry books with the highest percentage is the aspect of the presentation component that is equal to $86.47 \%$, then followed by aspects linguistic component of $85.01 \%$ and the lowest percentage is the aspect of the feasibility of the content with percentage of $83.22 \%$. From the results of questionnaire responses data analysis students, overall aspects obtained an average percentage of
$84.90 \%$. If the percentage score of $81 \%-100 \%$ then the category was very good. So from the results of student responses can be seen that the development of chemistry books based on science literacy on the material colloidal system included into the category very well. The evaluation stage is carried out during the chemical book development process in the form of advice of supervisor and validator suggestion during the validation process.

\section{CONCLUSIONS}

Chemistry-based literacy textbook on science on colloidal system materials developed with the ADDIE development model include the analysis phase, the design phase, the development stage, the implementation stage and the evaluation stage. Data obtained during the study were analyzed descriptively. Based on questionnaire data result of chemistry textbook science literacy based colloid material experiment the criteria very well with the percentage of $84.90 \%$ with details for the aspect of the feasibility of the contents of $83.22 \%, 86.47 \%$ for the presentation aspect, and $85.01 \%$ for the linguistic aspect.

\section{REFERENCES}

Arikunto, S. (2013). Prosedur Penelitian Suatu Pendekatan Praktik. Jakarta: Rineka Cipta

Arsyad, A. (2010). Media Pembelajaran. Jakarta: PT Raja Grafido Persada.

Chiappetta, E. L., Sethna, G. H., Fillman, D. A. (1991). A Quantitative Analysis of High School Chemistry Textbooks for Scientific Literacy Themes and Expository Learning Aids. Journal of Research in Science Teaching, 28(10), 939-951.

Coughlan, S. (2015). Asia Peringkat Tertinggi Sekolah Global, Indonesia Nomor 69 Citing Internet sources URL: $\quad$ http://www.bbc.com/indonesia/majalah/20 15/05/150513_majalah_asia_sekolah_terba ik

Dewantari, A., Ashadi, Sugiharto. (2013). Studi Komparasi Penggunaan Macromedia Flash dan Worksheet dalam Pembelajaran Kooperatif Metode Learning Cycle 5E pada Materi Pokok Koloid Kelas XI Semester Genap SMA Negeri 1 Surakarta Tahun Pelajaran 2012/2013. Jurnal Pendidikan Kimia, 2(4), 142-150.

Hayat, B., Yusuf, S. (2011). Benchmark Internasional Mutu Pendidikan. Jakarta: Bumi Aksara.

Kurnia, F., Zulherman., Fathurohman, A. (2014). Analisis Bahan Ajar Fisika SMA Kelas XI Di Kecamatan Indralaya Utara Berdasrkan Kategori Literasi Sains. Jurnal Inovasi dan Pembelajaran Fisika, 1(1), 43-47.

Marlina, L. (2015, Agustus 12). Wawancara Analisis Kesenjangan Kinerja. (V. Seftari, Pewawancara) 
Prastowo, A. (2011). Panduan Kreatif Membuat Bahan Ajar Inovatif. Jogjakarta: DIVA Press.

Sanjaya, W. (2008). Perencanaan dan Desain Sistem Pembelajaran. Jakarta: Kencana Prenada Media Group.

Sothayapetch, P. (2013). A Comparative Study of Science Education at the Primary School Level in Finland and Thailand. (Desertasi, University of Helsinki, Finlandia). Citing Internet sources URL https://helda.helsinki.fi/bitstream/handle/1 0138/42259/sothayapetch_dissertation.pdf?sequence $=1$

Susanti, M., Rusilowati, A. Susanto, H. (2015). Pengembangan Bahan Ajar IPA Berbasis Literasi Sains Bertema Listrik dalam Kehidupan untuk-Kelas IX. Unnes Physics Educaiton Journal, 4(3), 43-49.

Tarigan, H. G Tarigan, D. (2009). Telaah Buku Teks Bahasa Indonesia. Bandung: Angkasa Bandung.

Toharudin, U., Hendrawati, S., Rustaman, A. (2011). Membangun Literasi Sains Peserta Didik. Bandung: Humaniora.

Udeani, U. (2013). Quantitative Analysis of Secondary School Biology Textbooks for Scientific Literacy Themes. Research Journal in Organizational Pscychology and Educational Studies, 2(1), 39-43.

Yager, R. E. (1983). The Importance of Terminologi in Teaching K-12 Science. Journal of Research in Science Teaching, 20(6), 577-588.

Zulfiani., Feronika, T., Suartini, K. (2009). Strategi Pembelajaran Sains. Jakarta: Lembaga Penelitian UIN Jakarta. 